\title{
Cryptobiotic foraminifera from the Paleocene Kambühel Formation (northern calcareous Alps, Austria)
}

\section{Felix SCHLAGINTWEIT}

Lerchenauerstr. 167, 80935 München, Germany.

Received 15 February 2005; accepted 20 July 2005

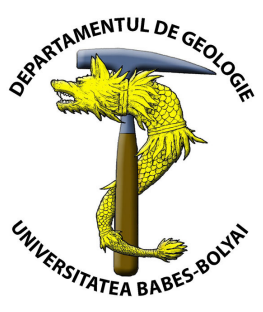

\begin{abstract}
Cryptobiotic foraminifera are described from Paleocene shallow-water limestones of the Kambühel Formation ("Kambühelkalk") of the south-eastern part of the Northern Calcareous Alps/Austria. They have been discovered within cavities occurring in the nodular thalli of the "solenoporacean" alga Parachaetetes asvapatii Pia, 1936. The foraminifera of uncertain generic status show an irregular planspiral coiling and thin walls. It is assumed that these forms were actively boring, not colonizing an excavation made by another organism. Whether these borings were excavated during the life-time of the alga or post-mortem, however, is uncertain. The micritic Parachaetetes bafflestones containing the described foraminifera were deposited in an environment of low energy, hence, protection against natural enemies and not against abrasive water-energy was the probable reason for their cryptobiotic way of life. Moreover, due to high diversity of encrusting taxa (foraminifera, red algae) the cavitydwelling mode of life occupied a vacant and non-competitive ecological niche. Parachaetetes thalli from reefal facies are devoid of these cryptobiotic foraminifera.
\end{abstract}

Key words: Cryptobiotic foraminifera, shallow water limestones, Kambühel Formation, Northern Calcareous Alps.

\section{INTRODUCTION}

Cryptobiotic foraminifera are forms living in cavities of other organisms either bored by the foraminifer itself or by others ("secondary cryptobionts") (see Matteucci, 1978, Cherchi \& Schroeder, 1990). The latter can also be termed "cavity dwellers or coelobites" (Wilson, 1987). Also foraminifera that lived in shaded areas, such as the underside of corals are approached as cryptobiotic (e.g. Matteucci, 1996, Bosellini \& Papazzoni, 2003).

Various different attachment-strategies (e.g. encrusting, boring and nestling communities, Wilson, 1987) have been developed by benthic foraminifera to settle on or within hard substrates. Special growth strategies on hard substrates are also known from bryozoans (e.g. runner-type etc., Voigt, 1988). According to Jones \& Charnock (1985: p. 316) attached foraminifera cannot groove and so have to feed on organisms they harvest with their pseudopodia near the site of the attachement.

Hofker (1965) and Voigt (1970) described arenaceous foraminifera belonging to the genera Placopsilina and Bdelloidina dwelling in walls of holes in hardgrounds of the Maastrichtian chalk-tuff of the Netherlands. Voigt (1970) assumed that the foraminifera lived in commensalism with the boring organisms for feeding participation. According to the authors, these cavities have been bored either by Calianassa (small crustaceans) or Phoronida, a class of wormlike Tentaculata.

Wilson (1986) described both arenaceous and calcareous foraminifera of the genus Rectocibicides Cushman \&
Ponton, Lapillincola Wilson, Acruliammina Loeblich \& Tappan and Bullopora Quenstedt from the Lower Cretaceous sponge-gravel of south-central England within borings in a "mobile hardground" of loose cobbles. They settle in the interiors of borings of the ichnogenus Gastrochaenolites Leymerie. Following the author, this micro-habitat served as a refuge from physical, abrasive test destruction in the loose gravels and also for protection against epifaunal predators.

Whereas the mentioned examples concern foraminifera that lived as secondary hosts in excavations made by other boring taxa, there are also forms that bored actively in carbonate substrates thus contributing to the bioerosion of hard substrates and the production of small size particles. Todd (1965) observed microborings in the shell of the bivalve Lima made by Rosalina carnivora dredged at $951 \mathrm{~m}$ in the Gulf of Guinea. He speculated that the foraminifer could provide building material for its own shell. Banner (1972) described the present-day foraminifer Planorbulinopsis parasita from the Indo-Pacific that lived endoparasitic in the larger foraminifer Alveolinella. The host was alive at the time of penetration and "the cytoplasma of the host must become a permanent home for the parasite" for an appropriate food supply.

Cherchi et al. (1990) described cryptobiotic foraminifera in the test of orbitolinids from the Albian of Egypt. The authors assume that penetration happened post-mortem after death of the orbitolinids with the purpose "to protect themselves against water turbulence or attacks of enemies". Ramified microborings in recent lamellibranch shells 
containing tests of endolithic foraminifera were described by Cherchi \& Schroeder (1991) from the eastern coast of Scotland. As in the case of the bored orbitolinid tests (example mentioned previously), the authors assume that the young specimens penetrated the shell after attachment on its surface. Also in this example, Cherchi \& Schroeder (1991) assumed an adaptation to life in turbulent environments. Wernli \& Fookes (1992) described the new foraminifera Troglotella incrustans from Kimmeridgian reefal limestones of France occupying small cavities within coral clasts. The authors refute a boring way of life but assume that Troglotella lived within already existing cavities. As was discussed by Schmid \& Leinfelder (1996: p. 38), "specimens of Troglotella were facultative borers during the juvenile growth stage" thus representing the oldest endolithic foraminifera known up to now.

Cherchi \& Schroeder (1994) illustrated thin-walled miliolids (? Istriloculina) as cryptobiotic foraminifera from the Early Barremian of S-France. Small young specimens were interpreted as a swarm of embryos that were reproduced by schizogony within the cavity.

Cherchi et al. (1995) reported on Tolypammina vagans (Brady) that colonized the chambers of a lituolid foraminifer from the Upper Albian to Lower Cenomanian of Spain. They also reported cryptobiotic foraminifera within the cavities of Lithocodium aggregatum Elliott that can be refered to Troglotella incrustans Wernli \& Fookes representing the youngest known occurrence of this taxon (e.g. Schmid \& Leinfelder, 1996).

The investigation of Paleocene shallow-water limestone of the Northern Calcareous Alps yielded interesting and so far not described cryptobiotic foraminifera. As these are interpreted representing active boring foraminifera, it is, according to our knowledge, the first proof of this group from Paleocene limestones.

\section{GEOLOGICAL SETTING}

The Kambühel Formation (Tragelehn, 1996) or Kambühel Limestone (sensu Tollmann, 1976), with the type-section at the Kambühel near Ternitz (Fig. 1), represents a Maastrichtian-Upper Paleocene carbonate platform that developed along the southern rim of the Northern Calcareous Alps.

It is well exposed in the easternmost part of the Northern Calcareous Alps and in the Mürzalpen (Plöchinger, 1967, Lein, 1982, Tragelehn, 1996). The latter author provided a detailed microfacies and stratigraphic analysis of the eastern Kambühel Limestone occurrences in his doctoral thesis.

Most of these occurrences are large olistolites reworked in the deeper water facies of the "Upper Gosau Subgroup". The recent finding in the Zwieselalm Formation (Schlagintweit at al., 2003) is the most western occurrence of these olistolites of the Gosau Group known so far (see Fig. 1). Further to the west, in the Inntal valley area, pebbles of equivalent Paleocene limestones are reported from Oligocene and Eocene conglomerates (Hagn, 1976, Moussavian, 1984). The most western occurrences of allochthonous Paleocene shallow water limestones are from Molasse conglomerates of the Allgäu area (Hagn, 1989). An eastern continuation of these Alpine Paleocene shallowwater limestones is well known from the Western Carpathians (Mišik, 1966, Samuel et al. 1972, Bucev \& Köhler, 1987).
The material described in the present paper comes from the localities Mooshuben (see Lein, 1982) and the Klein Ebenstein about $10 \mathrm{~km}$ northeast of Eisenerz Steiermark (Figs. 1, 2). The latter is located on the geological map of Austria $1: 25.000$, ÖK 101 Eisenerz and belongs to the Hochschwab area of the Mürzalp Nappe/Styria being part of the southeastern Northern Calcareous Alps (Fig. 1). The geology of this area is dominated by Middle Triassic limestones and dolomites (e.g. Lein, 2000; Mandl, 2000, 2002).

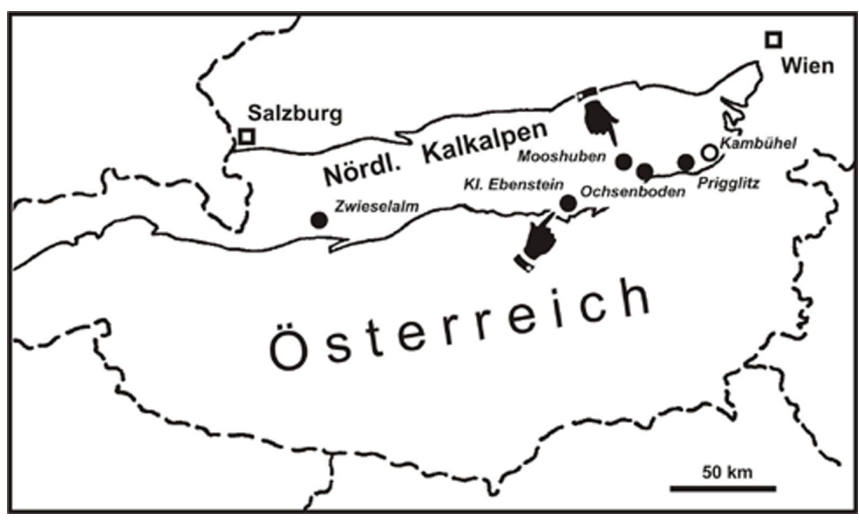

Fig. 1. Main occurrences of Paleocene shallow-water limestones in the Northern Calcareous Alps with localities Klein Ebenstein and Mooshuben.

The occurrence of Paleocene shallow-water limestones covering an area of more than $2 \mathrm{~km}^{2}$ was discovered only recently (Mandl, 2002, Kegler et al., 2000). According to Kegler et al. (2000) this occurrence was installed upon an isolated "island" of Triassic limestones /dolomites not showing any siliciclastic influx from the hinterland.

The thin-sections studied derive from the project coordinated by Mandl (2002, p. 157-160). The sample no. 98/92 containing cryptobiotic foraminifera is represented by a Parachaetetes bafflestone (P1. I, Fig. 1). Within the micritic matrix debris of corals (Pl. I, Fig. 9, Pl. II, Fig. 1), the tubes of serpulids including Carpathiella triangulata Mišik, Sotak \& Ziegler (P1. II, Fig. 4), Dasycladales with Broeckella belgica Morellet \& Morellet, Linoporella parva Dieni, Massari \& Radoičić (P1. II, Fig. 3), Terquemella sp., Neomeris-Cymopolia group, nodules of Polystrata alba (Pfender) Denizot (Pl. II, Fig. 1) and some miliolid foraminifera occur. Occasionally, the solenoporacean thalli show incrustations by Haddonia sp. (Pl. I, Figs. 4, 6) and coralline algae.

\section{MICROPALAEONTOLOGICAL PART}

A description of the alga Parachaetetes asvapatii Pia is not given here, for further details and discussions see Poignant (1980), Moussavian (1989) and Aguirre \& Barattolo (2001). Within the Alpine Paleocene Kambühel Formation Tragelehn (1997, p. 188) noticed a facies flexibility of $P$. asvapatii producing more close set elongate growth forms within open marine environment (incl. reefal facies) and isolated columnar growth types within quiet lagoon. Our samples are lagoonal wackestones with columnar solenoporacean nodules.

The cryptobiotic foraminifera described in the present paper have already been mentioned and illustrated in the literature. In their comprehensive review of the "Lithocodium-Troglotella consortium" Schmid \& Leinfelder (1996, Pl. 2, Fig. 7) also figured a "minute cryptic 


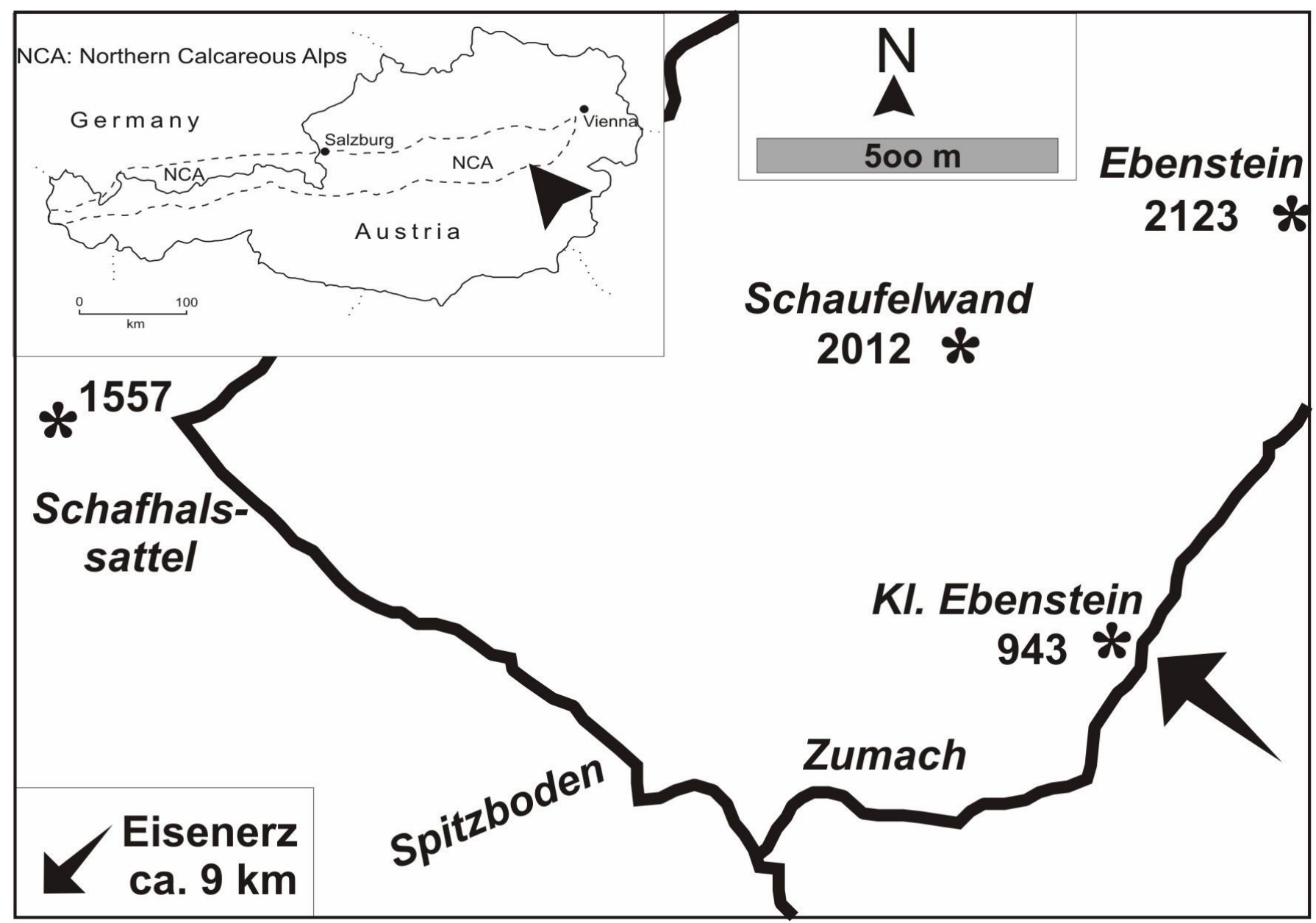

Fig. 2. Topographic sketch map of the Klein Ebenstein/Steiermark, Austria.

foraminifera with a very thin wall, occupying a chamber of Alveolina" from the middle Eocene of northern Spain. This form is identical to our Paleocene specimens from the Northern Calcareous Alps. As the host foraminifer $(>$ Alveolina) "clearly reacted by modifying and enlarging the infested chamber" a probable parasitic way of life was assumed by Schmid \& Leinfelder (1996: p. 42).

Tragelehn (1996) figured it as "Hohlraum-besiedelnde Foraminifere gen. et sp. indet" (= cavity dwelling foraminifera) on plate 53, Figs. 4-5 of his $\mathrm{PhD}$ thesis about the microfacies, micropalaeontology and stratigraphy of the Alpine Kambühel Formation.

\section{? Suborder Miliolina Delage \& Herouard}

Remarks: The forms are tentatively refered to the Miliolina as the typical brownish porcellaneous appearance of the wall is not evident, perhaps due to diagenetic effects or the extreme thin walls. The typical coiling observed, however, points to this group of foraminifera. For the time being, we refrain from any generic or suprageneric classification of this foraminifera undoubtedly necessitating further material for deciphering the whole test morphology (e.g. apertural features, chamber morphology etc.). Noteworthy that Cherchi \& Schroeder (1994) also reported boring miliolids (? Istriloculina) with thin walls from the Lower Cretaceous of France.

Description: Tests lenticular with rounded periphery and a biumbonal depression visible in axial sections (Pl. I, Fig. 4). The spherical proloculus (Pl. I, Fig. 2) is followed by an undivided coiled second chamber (Pl. I, Fig. 10). In axial sections, up to six whorls can be observed. The width of the tube increases very rapidly in size from one whorl to the next strongly overlapping previous whorls and appear crescent to sickle-shaped. The test wall is calcareous imperforate and extremely thin.

In some cases it can be seen that the cavity with the foraminifer inside is larger in diameter than the bored channel towards the thallus periphery (e.g. Pl. II, Fig. 4). Therefore it can be assumed that the juvenile foraminifer itself was actively boring the hole and than during ontogenetic growth successively enlarged the chamber made for living inside the solenoporacean algae.

Also we speculate that these tiny borings did not cause the death of the solenoporacean host and happened during the life-time of the latter and not post-mortem.

Of course the latter case could also happen since any other advantage as protection, e.g. some kind of commensalisms, seems not very probable. Noteworthy, that we never observed any other microfossil inside of the cavities.

Table 1. - Dimensions of the cryptobiotic foraminifera from the Paleocene Kambühel Formation. No. 2-3: measured from the figurations of Tragelehn (1996: Pl. 53, Figs. 4-5).

\begin{tabular}{|l|l|l|l|}
\hline No. & Test diameter $(\mathbf{d})$ & $\begin{array}{l}\text { Test width } \\
\text { umbilical part }\end{array}$ & $\begin{array}{l}\text { Maximum test } \\
\text { width }\end{array}$ \\
\hline 1 & $0.92 \mathrm{~mm}$ & $0.29 \mathrm{~mm}$ & $0.42 \mathrm{~mm}$ \\
\hline 2 & $0.92 \mathrm{~mm}$ & $0.46 \mathrm{~mm}$ & $0.54 \mathrm{~mm}$ \\
\hline 3 & $0.7 \mathrm{~mm}$ & $0.38 \mathrm{~mm}$ & $0.44 \mathrm{~mm}$ \\
\hline 4 & $0.3 \mathrm{~mm}$ & $0.13 \mathrm{~mm}$ & $0.16 \mathrm{~mm}$ \\
\hline
\end{tabular}


Dimensions: For the data set we only included more or less centered sections, hence, there are only some useful sections giving little informations on the biometric variability of the species. As the test display a biconcave shape, the two values are indicated, for the umbilical part and the maximum value represented by the width of the last chamber.

\section{CONCLUSIONS}

Small cryptobiotic foraminifera are a common constituent of the Paleocene Kambühel Formation where they occupied small cavities bored into the thalli of Parachaetetes asvapatii Pia. Due to the co-occurrence with dasycladales, the comparable scarceness of coralline red algae and the overall micritic matrix, a lagoonal setting is assumed. These cryptobiotic foraminifera may also occur within reefal facies, but much less frequent. Here, nearly all solenoporacean thalli show strong incrustations by corallinaceans, peyssonneliaceans, serpulids and foraminifera such as Haddonia, Planorbulina or Miniacina. Within corals these cryptobiotic foraminifera have not been observed. Obviously it was much easier to penetrate the porous solenoporacean thallus structure rather than more compact coral skeletons. Due to facies reasons, the cryptobiotic way of life cannot be explained as protection against abrasive water energy. The competition for settling upon hard substrates was very strong especially within reefal type facies with a high diversified association including numerous sessile foraminifera (e.g. Miniacina, Planorbulinella, Haddonia) and also red algae (Peyssonneliaceae, Corallinaceae) so that living inside of the substrate was an appropriate non-competitive ecological niche that also offered protection against predators.

Acknowledgements. The material studied has kindly been provided by G. Mandl and W. Pavlik (GBA, Vienna), H. Lobitzer (Bad Ischl) and R. Lein (University of Vienna). Helpful comments were provided by reviewer A. Cherchi (University of Caglari).

\section{R E F E R E N C E S}

Aguirre, J. \& Barattolo, F. 2001, Presence of nemathecia in Parachaetetes asvapatii Pia, 1936 (Rhodophyta, Gigartinales?): Reproduction in "solenoporaceans" revisited. Palaeont., 44 (6): 113-125.

Bosellini, F.R. \& Papazzoni, C.A. 2003, Palaeoecological significance of coral-encrusting foraminiferan associations: A case-study from the Upper Eocene of northern Italy. Acta Palaeontol. Pol., 48 (2): 279-292.

Bucev S. \& Köhler E. 1987, The Dasycladacean alga Sarosiella in the West Carpathians. Geol. Zbornik - Geol. Carpathica, 38 (6): 669-676.

Cherchi, A., Garcia, A., Schroeder, R. \& Segura, M. 1995, Foraminiferos cryptobióticos en el Albiense Superior Cenomaniense Inferior de la Cordillera Ibérica. Reflexiones sobre unas estructuras problematicás en Lithocodium. Rev. Esp. Paleont., 10 (2): 284-293.

Cherchi, A., Kuss, J. \& Schroeder, R. 1990, Foraminiferi criptobionti in gusci di Orbitolina e in bio- e lithoclasti dell'Albiano di Gebel Maghara (Peninsola del Sinai,
Egitto). In: Atti del Quarto Simp. Ecol. Paleoecol. delle Comunitá Bentoniche, (Robba, E., Ed.), Torino, Museo Regionale di Sci. Nat. Torino, 151-174.

Cherchi, A. \& Schroeder, R. 1991, Perforations branchues dues à des Foraminifères cryptobiontiques dans des coquilles actuelles et fossiles. C. R. Acad. Sci., 312, sér. II: $111-115$.

Cherchi, A. \& Schroeder, R. 1994, Schizogony of an Early Barremian cryptobiotic miliolid. In Ecology and Palaeoecology of Benthic Cimmunities, Boll. Soc. Paleont. Ital., spec. vol., 2 (Matteucci, R. et al., Eds.), Modena, 61-65.

Hagn, H. 1976, Neue Beobachtungen an Geröllen aus den Bayerischen Alpen und ihrem Vorland (Oberkreide, Altund Jungtertiär). Mitt. Bayer. Staatsslg. Paläont. Hist. Geol., 16: 113-133.

Hagn, H. 1989, Über einige bedeutsame Kreide- und Alttertiärgerölle aus der Faltenmolasse des Allgäus. Geol. Bavarica, 94: 5-47.

Kegler, P., Andrés, C. \& Tragelehn, H. 2000, Neukartierung der Gosau des Hochschwab-Gebietes (Steiermark /Österreich) - Ergebnisse zur Fazies, Biostratigraphie und Paläogeographie. Mitt. Ges. Geol. Bergbaustud. Österr. (Abstracts Sediment 2000), 43: 71-72.

Lein R. 1982, Vorläufige Mitteilungen über ein Vorkommen von flyschoider Gosau mit Komponenten paleozäner Riffkalke in den Mürztaler Alpen. Mitt. Ges. Geol. Bergbaustud. Österr., 28: 121-132.

Lein, R. 2000, Die Hallstätter Trias der Mürztaler Alpen. Mitt. Ges. Geol. Bergbaustud., 44: 289-296.

Mandl. G. (coord.), 2002, Erstellung moderner geologischer Karten als Grundlage für karsthydrogeologische Spezialuntersuchungen im Hochschwabgebiet. Endbericht BBK-Forschungsprojekt WA 4a/F2000 \& StA 028n/F2000, Geol.-B.A., 211 pp., Wien.

Mandl, G.W. 2000, The Alpine sector of the Tethyan shelfExamples of Triassic to Jurassic sedimentation and deformation from the Northern Calcareous Alps. Mitt. Österr. Geol. Gesellschaft, 92: 61-77.

Matteucci, R. 1978, Foraminiferi epibionti e criptobionti in gusci di Nummuliti dell'Eocene medio del Gargano (Puglia). Geol. Romana, 17: 389-410.

Matteucci, R. 1996, Autoecologic remarks on recent and fossil Haddonia (Textulariina, Foraminifera). In Autecology of selected fossil organisms: Achievements and Problems, Boll. Soc. Paleont. Ital., spec. vol. 3, (Cherchi, A., Ed.), Modena, pp. 113-122,

Mišik M. 1966, Microfacies of the Mesozoic and Tertiary Limestones of the West Carpathians. Slov. Akad. Vied, Bratislava.

Moussavian, E. 1984, Die Gosau- und Alttertiär-Gerölle der Angerberg-Schichten (Höheres Oligozän, Unterinntal, Nördliche Kalkalpen). Facies, 10: 1-86.

Moussavian, E. 1989, Über die systematische Stellung und die Bestimmungskriterien der Solenoporaceen (Rhodophyceae). Cour. Forsch. Inst. Senckenberg, 109: 51-91.

Moussavian, E. 1993, Facies development of the Eastern Alpine Paleogene with regard to algal associations. Facial development of algae-bearing carbonate sequences in the Eastern Alps, Field Trip Guide book, (Höfling, R., Moussavian, E. \& Piller, W., Eds.), München.27 pp.

Plöchinger B. 1967, Erläuterungen zur Geologischen Karte des Hohe-Wand-Gebietes (Niederösterreich) 1:25.000. Wien, (Geol. B.-A.). 
Poignant, A.-F. 1980, Sur deux algues calcaires du Crétacé Supérieur du Nord de 1' Espagne. Réflexions sur le genre Elianella. 105 Congr. nat. Soc. savantes, Caen, 1980, fasc. II: 323-328.

Samuel, O., Borza, K. \& Köhler, E. 1972, Microfauna and lithostratigraphy of the Paleogene and adjacent Cretaceous of the Middle Váh Valley (Western Carpathians). Geol. Ust. Dionýza Stúra, Bratislava, $246 \mathrm{pp}$.

Schmid, D.U. \& Leinfelder, R.R. 1996, The Jurassic Lithocodium aggregatum-Troglotella incrustans foraminiferal consortium. Palaeontol., 39 (1): 21-52.

Schlagintweit, F., Švábenická, L. \& Lobitzer, H. 2003, An occurrence of Paleocene Reefal Limestone in the Zwieselalm Formation of Gosau (Upper Austria). In Beiträge zur Geologie des Salzkammergutes, Gmundner Geo-Studien, (Weidinger, J.T., Lobitzer, H. \& Spitzbart, I., Eds.), Gmunden, 173-180.

Smyth, M.J. 1988, The foraminifer Cymbaloporella tabellaeformis (Brady) bores into gastropod shells. Journ. Foram. Res., 18 (4): 277-285.

Todd, R. 1965, A new Rosalina (Foraminifera) parasitic on a bivalve. Deep Sea Res., 12: 831-837.

Tollmann A. 1976, Monographie der Nördlichen Kalkalpen. Teil II. Analyse des klassischen nordalpinen Mesozoikums. Stratigraphie, Fauna und Fazies der Nördlichen Kalkalpen. Franz Deuticke, Wien, 580 pp.
Tragelehn, H. 1996, Maastricht und Paläozän am Südrand der Nördlichen Kalkalpen (Niederösterreich, Steiermark) - Fazies, Stratigraphie Paläogeographie und Fossilführung des "Kambühelkalkes" und assoziierter Sedimente. Diss. Naturwiss. Fak. University Erlangen, Erlangen, $216 \mathrm{pp}$.

Venec-Peyre, M.T. 1987, Boring foraminifera in French Polynesian coral reefs. Coral Reefs, 5: 205-212.

Venec-Peyre, M.T. 1988, Two new species of bioeroding Trochamminidae (Foraminiferida) from French Polynesia. J. Foram. Res., 18 (8): 1-5.

Voigt, E. 1970, Foraminiferen und (?) Phoronidea als Kommensalen auf den Hartgründen der Maastrichter Tuffkreide. Paläont. Z., 44 (1-2): 86-92.

Voigt, E. 1988, Wachstums- und Knospungsstrategien von Grammothoa filifera Voigt \& Hillmer (Bryozoa, Cheilostomata, Ob. Kreide). Paläont. Z., 62 (3-4): 193203.

Wernli, R. \& Fookes, E. 1992, Troglotella incrustans n. gen., n. sp., un étrange et nouveau foraminifère calcicavicole du complexe récifal kimméridgien de SaintGermain-de-Joux (Ain, France). Boll. Soc. Paleont. Ital., 31: 95-103.

Wilson, M.A. 1986, New adherent foraminiferans from the Lower Cretaceous (Aptian) of south-central England. $J$. Micropaleont., 5 (2): 1-8. 

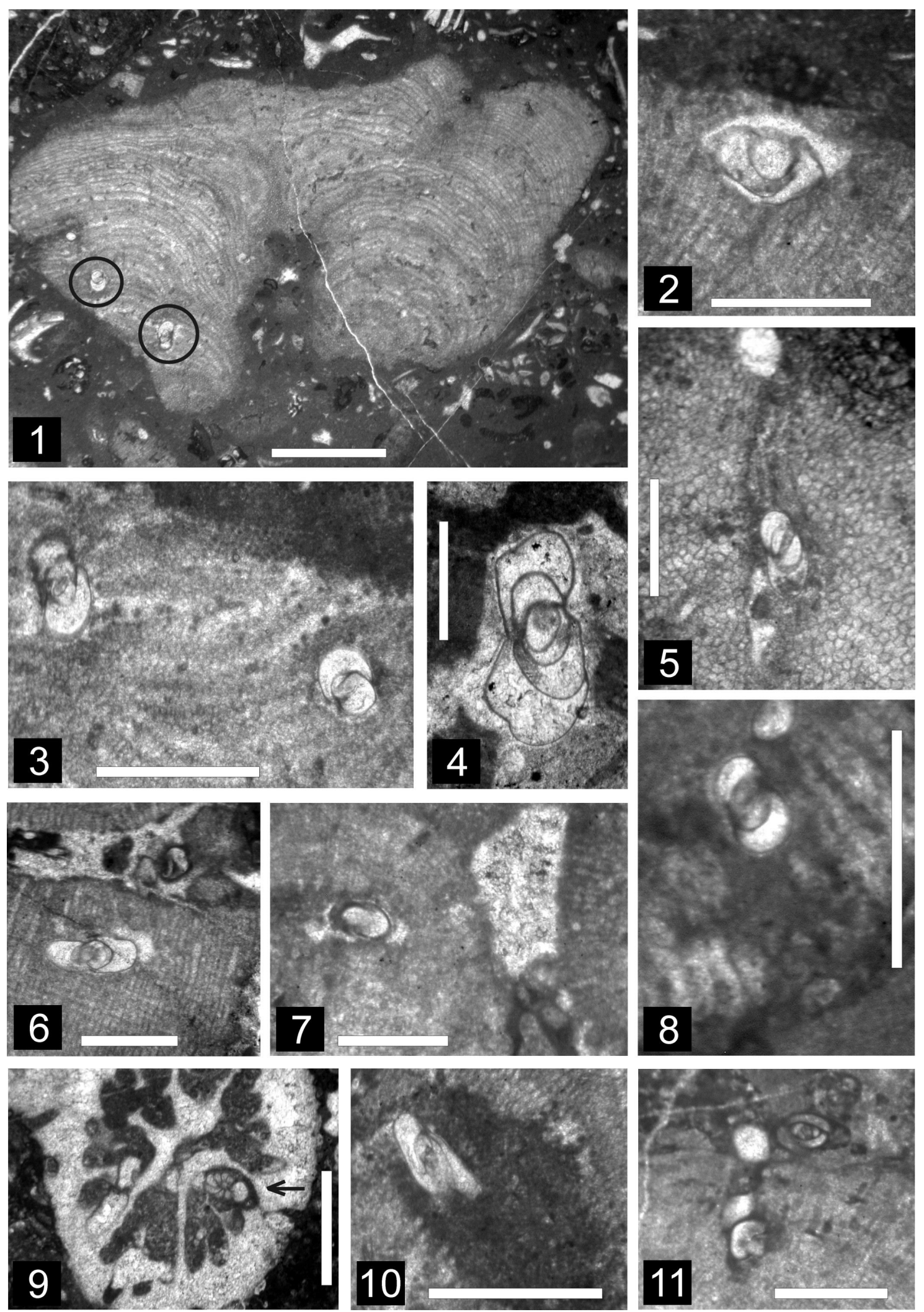

Plate I (Figs. 1-3, 6-8, 10 from Klein Ebenstein; Figs. 4-5, 9 from Mooshuben)

Fig. 1. Parachaetetes bafflestone showing two cryptobiotic foraminifers on the lower left side of the thallus marked by two black circles. Scale bar $=2 \mathrm{~mm}$.

Figs. 2, 3. (detail from Fig. 1), 5-8, 10-11 Cryptobiotic foraminifera within Parachaetetes thallus. Scale bar $=0.5 \mathrm{~mm}$.

Fig. 4. Axial section of cryptobiotic foraminifera with irregular coiling and sickle-shaped

chamber sections. Scale bar $=0.5 \mathrm{~mm}$.

Fig. 9. Cryptobiotic foraminifera within corallite. Scale bar $=0.5 \mathrm{~mm}$. 

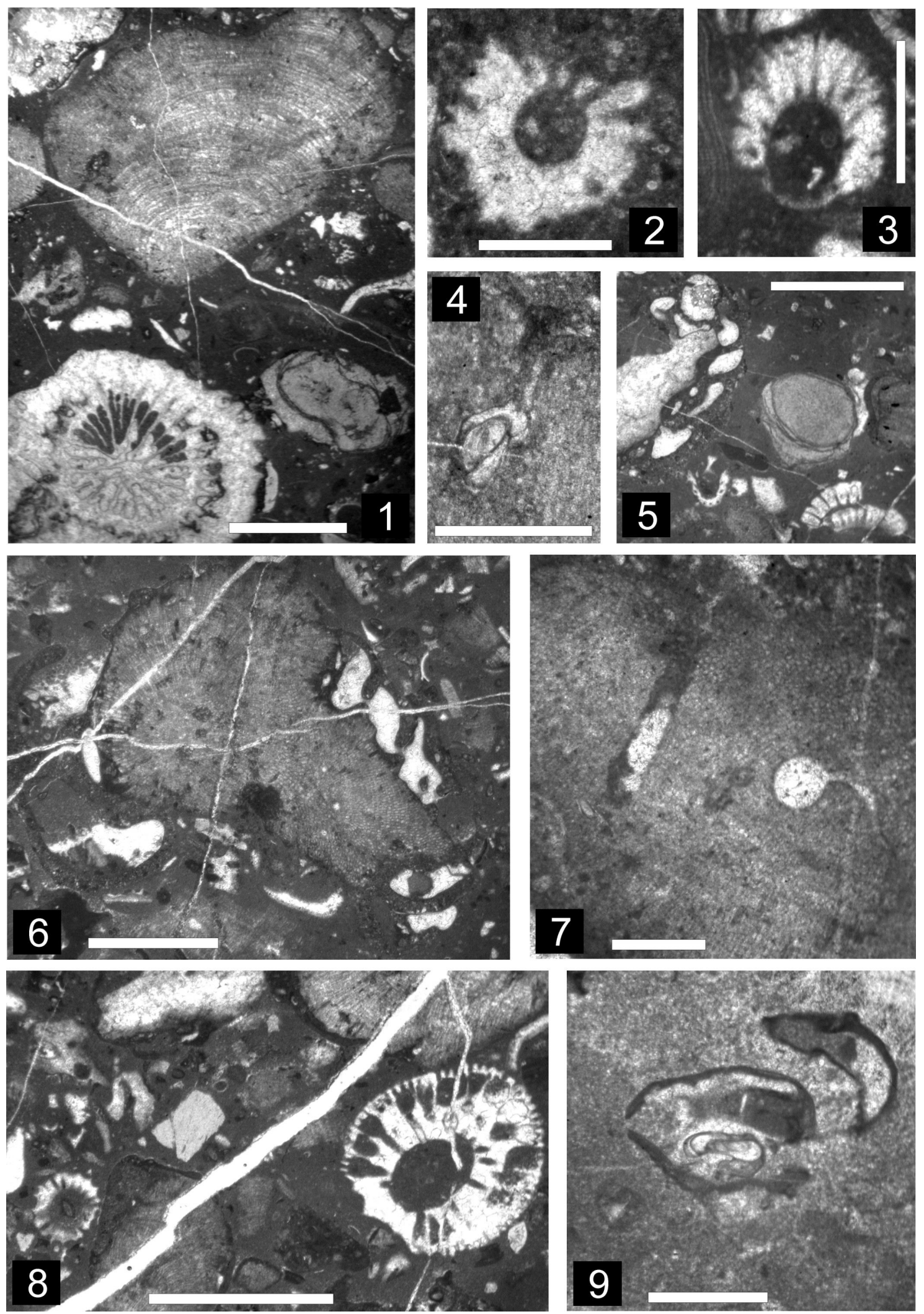

Plate II (All figures from Klein Ebenstein)

Fig. 1. Microfacies with corals, Parachaetetes asvapatii Pia, remains of dasycladales and peyssonneliacean Polystrata alba (Pfender) Denizot (right below). Scale bar $=2 \mathrm{~mm}$.

Fig. 2. "Dasycladacean S 2" sensu Dieni, Massari \& Radoičić 1985. Scale bar $=0.5 \mathrm{~mm}$.

Fig. 3. Dasycladale Linoporella parva Dieni, Massari \& Radoičić, oblique section. Scale bar $=0.5 \mathrm{~mm}$.

Figs. 4, 9. Cryptobiotic foraminifers within Parachaetetes asvapatii Pia. Scale bar $=0.5 \mathrm{~mm}$.

Fig. 5. Encrusting foraminifera Haddonia sp., remains of dasycladales and peyssonneliacean Polystrata alba (Pfender) Denizot. Scale bar $=2 \mathrm{~mm}$.

Fig. 6. Encrusting foraminifer Haddonia sp. growing on Parachaetetes asvapatii Pia. Scale bar $=2 \mathrm{~mm}$.

Fig. 7. Boring cavities within Parachaetetes asvapatii Pia. Scale bar $=0.5 \mathrm{~mm}$.

Fig. 8. Dasycladale Broeckella belgica Morellet \& Morellet (right) and dasycladale indet. (left). Scale bar $=2 \mathrm{~mm}$. 